\title{
Mensenrechten: een seculiere religie met juridische koevoeten?
}

\author{
Serge Gutwirth en Paul De Hert \\ Professoren, Faculteit Recht en Criminologie, Vakgroep Metajuridica, \\ Onderzoeksgroep Law, Science, Technology \& Society, Vrije Universiteit Brussel.
}

\begin{abstract}
'Les droits de l'homme sont des axiomes : ils peuvent sur le marché coexister avec bien d'autres axiomes, notamment sur la sécurité de la propriété, qui les ignorent ou les suspendent encore plus qu'ils ne les contredisent ... Quelle social-démocratie n'a pas donné l'ordre de tirer quand la misère sort de son territoire ou ghetto'

G. Deleuze \& F. Guattari, Qu'est-ce que la philosophie? Editions de Minuit, Paris, 1991, 104
\end{abstract}

'There is a crack in everything, that's how the light gets in'

Leonard Cohen

Het oeuvre van onze fijne collega Sonja Snacken heeft in de loop van de jaren '90 een duidelijke wending genomen, waarbij zij aan haar beheersing van het penologische vakgebied een bijkomende juridische dimensie heeft gevoegd, met name de bescherming van de rechten van de mens. Dit heeft geleid tot een overtuigd en uitgesproken wetenschappelijk onderbouwd humanistisch activisme waarin de bescherming van de fundamentele rechten en vrijheden van van hun vrijheid beroofde personen, een cruciale plaats heeft gekregen. Wij zijn wellicht en enigszins aan deze wending medeplichtig omdat we hierover samen met haar, of afzonderlijk met haar, onderzoek verricht en publicaties gepleegd hebben, en dit vanuit een verwant perspectief. ${ }^{2}$ In

2 P. De Hert, S. Gutwirth, S. Snacken \& E. Dumortier, 'La montée de l'Etat pénal: que peuvent les droits de l'homme ?', in Y. Cartuvels, H. Dumont, Fr. Ost, M. Van De Kerchove \& S. Van Drooghenbroeck (Eds), Les droits de l'homme: bouclier ou épée du droit pénal ?, Publications des FUSL/Bruylant, Bruxelles, 2007, 235-290: S. Gutwirth \& S. Snacken, 'Hoeveel onrechtmatigheid is onmenselijk of vernederend ? Noot bij Aerts t. België, E.H.R.M. 30 juli 1998', ICM-Jaarboek Mensenrechten 1998-2000, Ant- 
wat ongetwijfeld één van haar belangrijkste geschriften is, het samen met Dirk van Zyl Smit geschreven referentiewerk, Principles of European prison law and policy. Penology and human rights, veruiterlijkt het hoofdstuk over mensenrechten in een democratische rechtsstaat een vruchtbare en heerlijke interactie met ons werk.

Zelfs al bleek uit een aantal gemeenschappelijke publicaties dat de mensenrechten duidelijk hun limieten hebben, ${ }^{3}$ en dat dit nog een stuk scherper blijkt als 'menselijke waardigheid' eerder dan 'vrijheid' in dit kader ten tonele verschijnt, toch heeft Sonja op dat vlak nooit ingebonden. Haar 'radicaal humanisme' (dixit herself) steunt op de mensenrechten, en dan vooral op de mensenrechten zoals die in het Europees Verdrag voor de Bescherming van de Rechten van de Mens (EVRM) zijn verwoord en verder worden geconcretiseerd door het Hof van Straatsburg, met uiteraard een toespitsing van de aandacht op kwesties van vrijheidsberoving en op de werking van het Europees verdrag voor de voorkoming van foltering en onmenselijke of vernederende behandelingen, een werking die zij als bevoorrechte getuige van binnen en van buiten kent, en als geen ander in de vingers heeft. Het feit dat dit verdrag een tastbaar preventief dispositief op locatie opzet, waarin zij ook daadwerkelijk gewerkt heeft, maakt dit mensenrechteninstrument evenwel atypisch en in elk geval erg doortastend vergeleken met de grote meerderheid teksten van het internationaal mensenrechtenrecht, wat misschien haar mensenrechtenhumanisme nog versterkt heeft.

In voorliggende hulde willen wij het gesprek en de discussie met Sonja verderzetten op het vlak van de mensenrechten en de democratische rechtsstaat. ${ }^{4}$ Maar onze standpunten zullen een stuk minder optimistisch zijn. Geïnspireerd door wijlen François Rigaux zullen we eerst de mensenrechten als een seculiere religie benaderen ${ }^{5}$, om ze daarna weer te aarden in juridische grond, waar ze nuttige breekijzers of koevoeten kunnen blijken.

werp, MAKLU, 2002, 154-161; S. Snacken, C. Devynck, W. Distelmans, S. Gutwirth \& C. Lemmens, «Demandes d'euthanasie en prison. Souffrance psychique entre dignité humaine et peine de mort ? ", Criminologie, Justice et Santé Mentale, Vol. 48, n 1 , 2015, 102-122.

3 Zie de publicaties vermeld in voetnoot 148.

4 De discussie over de plaats van de menselijke waardigheid in het mensenrechtendiscours en instrumentarium zullen we op een andere plaats voeren.

5 F. Rigaux, La loi des juges, Odile Jacob, Paris, 1997, 320p. 


\section{Het seculier liberaal stichtingsverhaal}

Westerse democratische rechtsstaten koesteren diep verankerde stichtingsverhalen die door hun grondwetten worden uitgedrukt en via kolonisatie en economische voort-kolonisatie overal succesvol werden geëxporteerd en verankerd in de verdragen van hedendaagse internationale en supranationale organisaties die meestal gelden als hogere normen. In die zwaarwegende nationale en internationale normen wordt de westerse staatsvorm verheven tot een axioma, een universele maatstaf van politieke organisatie en institutionalisering. Het stichtingsverhaal wordt dikwijls genaturaliseerd (voor auteurs als Fukuyama maakt het zelfs een einde aan geschiedenis ...) en haar basisbegrippen - rechtsstaat, democratie, mensenrechten - hebben dikwijls iets van heilige koeien waarrond men zeer behoedzaam moet langslopen, zelfs als ze serieus in de weg staan voor iets anders. Het subsidiaire ordewoord dat het in elk geval toch gaat om het minst slechte systeem, vergroot er de onvermijdelijkheid van, want het wordt voorgesteld als het best haalbare, waarmee mogelijks beter zonder meer van tafel moet worden geveegd als irrealistische utopie. ${ }^{6}$

Binnen de variaties van het stichtingsverhaal is die mét sociaal contract het meest verbreid in het onderwijs en ook algemeen het best gekend. Tussen de chaos van het 'ieder voor zich' en de absolute macht van de soeverein ontvouwt zich -in een wisselspel tussen politieke bewegingen en filosofische ideeënontwikkeling- een tussenweg waarin een staatsmacht wordt opgetrokken die ervoor moet zorgen dat individuen hun fundamentele ('natuurlijke') vrijheden en rechten misschien niet onbeperkt, maar toch maximaal en substantieel kunnen genieten. Juist omwille van dat laatste punt kan die staatsmacht zich legitiem noemen, want de 'oersoevereiniteit' behoort immers, en dat is de fundamentele aanname, toe aan de individuele mens, met zijn vrijheid en zijn eigendom. Met andere woorden wordt een orde ingericht die, paradoxaal genoeg, vrijheid mogelijk maakt en garandeert. Voor Locke en Beccaria gebeurt dat via een sociaal contract dat draait rond vrijheid of vrijheden: burgers dragen een minimaal deeltje van hun soevereiniteit aan de staat over, die dan als tegenprestatie het gros van hun eigendommen en vrijheden moet beschermen: die staat voert politie en straft om de vrijheid van

6 Er zijn natuurlijk - 'gelukkig' wat ons betreft- ook iconoclasten, maar die zijn minoritair. Zo schrijven G. Deleuze en F. Guattari, om er maar een paar te noemen, ondubbelzinnig: 'L'européanisation ne constitue pas un devenir, elle constitue seulement l'histoire du capitalisme qui empêche le devenir des peuples assujettis'; G. Deleuze \& F. Guattari, Qu'est-ce que la philosophie? Éditions de Minuit, Paris, 1991. We komen op dat andere verhaal verder nog terug. 
de bedreigde enkelingen te beschermen (de nachtwakersstaat). Bij Hobbes, Rousseau en Kant is het verhaal complexer, in de zin dat er ook plaats wordt gemaakt voor zoiets als de publieke zaak (de res publica). In de hedendaagse politieke Westerse zelfvoorstelling zijn heel wat mengvormen te ontwaren, maar een constante is wel dat staten, naast de rechten van andere individuen ook het algemeen belang, in meer of mindere mate, kunnen inroepen om begrenzingen aan de individuele basisvrijheid of -soevereiniteit te legitimeren en in te voeren. ${ }^{7}$

\section{Eigendom, vrijheid en staatsbeperking: de pijlers van het gestichte verhaal}

Vanzelfsprekend sluit het liberale stichtingsverhaal met zijn historische selectie en creatie van instituten, vertegenwoordingsmechanismes, rechten en vrijheden naadloos aan bij de belangen van de zich in de $17^{\text {de }}-18^{\text {de }}$ ontwikkelende handelaarsstand of tiers état die vanuit de rijkdom verworven door handel en productie, de macht en invloed van de adel en clerus onder druk zet: vrijheid van handel(en), veiligstelling van eigendom en investeringen, bescherming en rechtszekerheid tegen de willekeur van de machthebbers én tegen het geweld van het onvoorspelbare plebs. Dat proto-kapitalistische proces begon nog het vroegst in Engeland met de brutale ontmanteling van de commons (zeer tegen de zin van de later uit de weg geruimde Thomas More die er de destabiliserende gevolgen - honger en opstanden - voor de ordehandhaving van voorzag) en de opkomst van protestante handelaars in het kielzog van Thomas Cromwell. ${ }^{8}$ Locke voegt daar nog een geweldige vondst aan toe: hij verbindt het in het verhaal cruciale eigendomsrecht ${ }^{9}$ aan

7 Voor sociale wetenschappers is zo'n stichtingsverhaal vanzelfsprekend een construct dat geen empirische basis heeft, want niemand heeft ooit een contract met alle anderen afgesloten. Dat neemt niet weg dat het grondslagentheoretische verhaal zeer reële instituties schraagt en ook in de praktijken die daaruit voortvloeien (de politieke en juridische praktijken bijvoorbeeld) voor legitimatie en referentie zorgt.

8 Zie over deze ontwikkelingen de mooie historische romans van Hilary Mantell Wolf Hall (2009), Bring up the bodies (2012) and The mirror \& the light (2020).

9 Voor Locke is het eigendomsrecht individueel en exclusief en het maakt deel uit van dé basis-set natuurlijke rechten waar alles ontspringt en begint: life, liberty and estate. Voor de Amerikaanse revolutionairen wordt die basis-set van natuurrechten in 1776, onder invloed van het utilitarisme van Bentham, 'life, liberty and the pursuit of hapiness', terwijl de Déclaration van 1789 'la liberté, la propriété, la sûreté, et la résistance à l'oppression' verheft tot 'droit naturels et imprescriptibles'. Het weze duidelijk dat de verklaringen niet het werk zijn van politieke filosofen maar van revolutionairen die daarbij filosofisch werk naar hun hand zetten in functie van de constellatie en noden van de plek, het moment, de situatie. 
productiviteit en 'dus' aan de algemene welvaart. Eigendom moet sterk gehandhaafd worden want daarmee zal de productiviteit stijgen en dat is goed voor iedereen (tegenwoordig noemt men dat de trickle down doctrine: rijken worden zo rijk dat de anderen er met de kruimels ook op zouden vooruitgaan). Het werd een dubbelslag want ook buiten Europa werkte het geweldig goed: de inheemse bevolking in Noord-Amerika was zo stupide om alleen maar te 'genieten' van de oogst van het land zonder het te extractief te exploiteren en productief te maken en kon er daardoor bijgevolg ... géén eigendomsaanspraak op maken. Dat land werd dus volgens de Lockedoctrine meteen terra nullius verklaard en daarop bloederig maar 'rechtmatig' toegeëigend door de nieuwkomers die natuurlijk wel zo slim waren geweest het eigendomsrecht uit te vinden en het daar, ongetwijfeld met het algemeen welzijn voor ogen, samen met henzelf importeerden. ${ }^{10}$

In alle versies van het Westers stichtingsverhaal wordt steevast gehamerd op twee must-haves: én fundamentele vrijheden (grondrechten), én rechtsstatelijkheid dienen te worden voorzien als buffers tegen overdreven en als vrijheidsdodend gedefinieerde staatsmachtsuitoefening.." De grondrechten en fundamentele vrijheden functioneren niet alleen als schilden tegen de macht uitgeoefend op individuen (dat is hun 'negatieve' of afwerende kant); maar ook als grondslag voor de participatie en emancipatie van de individuen in het collectieve en politieke gebeuren (dat is hun 'positieve' of emancipatorische kant, cf. Benjamin Constant en Isaiah Berlin). ${ }^{12}$ De checks en balances, de volgende poot van het verhaal, zorgen er dan weer voor dat legitieme machtsuitoefening alleen aanvaardbaar is wanneer ze pluricentrisch

10 S. Gutwirth \& I. Stengers, 'Le droit à l'épreuve de la résurgence des commons', Chronique: Théorie de droit, Revue Juridique de l'Environnement (RJE), 2016/1, p. 306-343.

11 Beide onderdelen, evenwicht der machten en grondrechten, treffen we al aan Locke's Two Treatises, waarin de oprichting en het functioneren van de wetgevende en de uitvoerende macht wordt beschreven, met de uitdrukkelijke boodschap dat de ingestelde politieke gemeenschap er niet zomaar is, maar als doel heeft de naleving van grondrechten te verzekeren ('the mutual preservation of their lives, liberties and estates').

12 De hoofdrol is zoals gezegd weggelegd voor eigendom, zeker bij Locke die zowel een eng ('estate') als een breed eigendomsbegrip hanteert ('property'), waarbij het brede begrip ook het recht op zelfbehoud omvat en in meer of mindere mate dus ook het recht op individuele vrijheid. In het eerste hoofdstuk van de tweede Treatise luidt het dat de politieke machten (de wetgevende en de uitvoerende) eigendom moeten reguleren en behouden. Het negende hoofdstuk ('Over de doeleinden van politieke samenleving en staatsbestuur') stelt onomwonden dat 'het eerste en voornaamste doel waarom mensen zich in een gemenebest verenigen en zich onder staatsbestuur stellen, is derhalve de instandhouding van hun eigendom is' (\$124). 
is of wanneer par la disposition des choses, le pouvoir arrête le pouvoir, zoals Montesquieu het formuleerde. Tevens nog is het bestuur gebonden aan zijn eigen spelregels, en kan het slechts politiek legitiem blijven als het kan worden gereconstrueerd als de spreekwoordelijke 'emanatie van de wil van het volk' of volkssoevereiniteit (verkiezingen, representatie, etc.).

Vanaf de twintigste eeuw kwam er een derde must-have bij en kreeg het verhaal van de superioriteit van het Westers politiek systeem zijn huidige vorm: een vorm van consensus groeide over de democratie als optimaal kader om vorm te geven aan politieke structuren die waken over de grondrechten van de burgers. ${ }^{13}$ Met deze koppeling presenteerden en presenteren Westerse democratische rechtsstaten zich graag als uitvinders en hoeders van de bestuursvorm die dictators en autocraten heeft uitgebannen, zelfs al is die democratie quasi geheel tot de majority rule herleid (met 49,9\% emaneer je de wil van het volk niet, met 50,1\% wel). ${ }^{14}$ Gewapend met de retorische kracht van het wonder van 'universele' mensenrechten, -wie niet mee is, is 'illegitiem'-, matigde het liberale universalisme zich het recht en de plicht aan om zijn orde aan de rest van de wereld op te leggen. ${ }^{15}$

Het verhaal gaat zelfs nog een stap verder: het beweert ook komaf te maken met de tirannie van de meerderheid, zoals J.S. Mill dat noemde, juist omdat het fundamentele rechten en vrijheden erkent en via onafhankelijke rechters, de derde poot van de macht, daadwerkelijk beschermt ook tegen aantastingen door de overheid. Zo wordt de idee van evenwicht van drie machten tegelijk ook een garantie voor het respect door allen en de staat van de 'erkende' of 'bevestigde' natuurrechten. ${ }^{16}$

13 Over de rol van denkers zoals Habermas (op rationale gronden) en Rorty (op pragmatische gronden) in het creëren van deze 'onvermijdelijke samenhang' tussen rule of law, mensenrechten en democratie, leze men Chantal Mouffe, Over het politieke, Kampen: Pelckmans, (2005), 2008, 93-98.

14 Over de basisingrediënten van de democratische rechtsstaat, zie S. Gutwirth, 'De polyfonie van de democratische rechtsstaat' in Wantrouwen en onbehagen, M. Elchardus, (red.), Balans 14, Brussels, VUBPress, 1998, 137-193.

15 Chantal Mouffe, Over het politieke, Kampen: Pelckmans, (2005), 2008, 85-88, met verwijzing naar het werk van Carl Schmitt die als eerste de vinger legde op het gebruik door het liberaal universalisme van universalistische en humanistische begrippen als ideologische wapens voor imperialistische expansie.

16 Dit heeft tot noodzakelijk gevolg dat democratische rechtsstaten in principe kleurrijk moeten zijn, want het betekent niets anders dan dat diversiteit van gedachten, visies, opinies, gedrag, relaties, 'opvattingen over het goede leven' en 'levensbeschouwingen' er een wezenskenmerk van zijn: individuele mensenrechten. Homogeniteit, monofonie en identiteit behoren te wijken voor heterogeniteit, polyfonie en diversiteit. De gedachten, de woorden en het gedrag zijn vrij: de eerste absoluut, de tweede een beetje minder absoluut, en het derde maximaal, tot het botst met gedrag van anderen, het algemeen belang of de publieke zaak. Althans, dat is in principe zo, t.w. zoals het in de 


\section{De democratische rechtsstaat: het verhaal in de grondwetten}

Dat het verhaal van de democratische rechtsstaat een oersterk en succesvol verhaal is, kan niemand betwijfelen. Het is immers het ijkpunt van 250 jaar staatsleer, staatsvorming en politieke legitimering juist in dat deel van de wereld dat in die periode zo machtig was dat het zowat alle andere staten, samen met haar symbioten de 'vrije markt' en het 'productivisme', heeft veroverd of besmet. Het is en blijft een verhaal dat in de eerste plaats behoort tot het register van de politieke filosofie, het economisch denken en natuurlijk ook dat van botsende belangen en machtsverhoudingen. Maar dat neemt niet weg dat het ook (en dikwijls door politieke strijd en compromissen, in verhakkelde vorm) werd vertaald in het kleed van erg zwaarwegende formele rechtsbronnen, de grondwetten. Westerse grondwetten zijn de veruiterlijking van de liberale rechtsstatelijke én vertegenwoordigende democratie (wat overigens, voorbij de liberale Verlichting, teruggaat tot de Gleichursprunklichkeit van democratie en rule of law in de oude Atheense polis). Met wat verbeelding kan worden gesteld dat ze het oer-Sociaal Contract belichamen dat onze stichtende de voorouders allemaal met allemaal hebben ondertekend, figuurlijk en 'utopisch' gesproken natuurlijk, en dat we in principe slechts hoogst uitzonderlijk kunnen heronderhandelen. Vanuit dit oogpunt is de Amerikaanse grondwet the supreme law of the land, het EVRM een soort allerhoogste norm voor de lidstaten van de Raad van Europa en sacraliseren de WHO-verdragen de 'wetten van de markt' als globale constitutie, veel meer overigens, dan de VN-mensenrechtenverklaringen en -verdragen. Indien zij belangrijk zijn, is dat, los van afdwingbaarheid, eerst en vooral te wijten aan het feit dat het sterke politieke documenten zijn: politieke verklaringen die meestal op basis van geaffirmeerde macht met een verleden breken en de toekomst willen maken en beheersen. Zij brengen een door de geschiedenis mogelijk gemaakt verhaal, dat moet instaan voor de vereeuwiging van een overwinning en het programma dat die deed ontluiken. Daarnaast zijn het ook formele rechtsbronnen, die een impact hebben op het werk dat juristen, hoven en rechtbanken zullen leveren.

politieke architectuur van de mensenrechtenverdragen en de grondwetten geboekstaafd staat. Dit facet van de rechtsstaat leidt ook tot spanningen met nationalistische en identitaire bewegingen, die geen blijf weten met de vrijheid van de minderheid en de individuen om te verschillen van wat de groepsidentiteit nu juist definieert. Hiernaast tieren heel wat informatie en communicatietechnieken van culturele homogenisatie, nivellering en afstomping welig. 
Vermits grondwetten veelal een grote mate van abstractie vertonen en op zichzelf uiteraard niet kunnen volstaan, wordt de politieke macht doorgaans verder gedelegeerd aan instituties, die dan worden verondersteld krachtens en in overeenstemming met de grondwet te handelen. Een grondwet is dan een soort basisaxioma (cf. 'axiomatisch recht') waar het geheel legislatief systeem is aan opgehangen en wordt verondersteld uit voort te vloeien (cf. de droom van Kelsen). Maar anders dan in de meetkunde kan er hier van mathematische juistheid geen sprake zijn, want elke deductie is een interpretatie en niet elke uitrekking van de door de grondwetten getekende limieten wordt de facto gecontroleerd of betwist. De op de grondwetten voortbouwende ondergeschikte wetgeving wordt dan ook verondersteld het grote project verder te zetten, maar op een zodanige wijze dat het kan voortleven in complexe situaties en nieuwe omstandigheden. ${ }^{17}$

\section{De democratische rechtsstaat: de praktijk}

We begonnen onze bijdrage met een uitspraak van Deleuze en Guattari over de mensenrechten als axioma onder en naast (andere) axioma's. Hun visie is ontnuchterend: je mag zoveel democratische rechtsstaat en mensenrechten hebben als je wil, er blijven geheel onaanvaardbare dingen gebeuren, onder meer bij het neerslaan van betogingen van de armen. ${ }^{18}$ Maar de voorbeelden mogen natuurlijk ook veel ruimer worden bekeken. Onze democratische rechtsstaten hebben zich tenslotte schromelijk verrijkt ten koste van de rest van de wereld met een toxisch mengsel van slavernij, plundering, extractie, racisme en vervuiling ingebed in een - al dan niet seculiere - 'humanistische'

17 Daardoor stellen zich steeds open vragen, waarop constitutionele rechters slechts zelden op duidelijke en consequente wijze antwoorden kunnen formuleren. Casuïstiek leent zich niet tot reductie van complexiteit, integendeel. Dat zal nog blijken als we het over de mensenrechten gaan hebben.

18 Over het brutaal politieoptreden bij betogingen van gele hesjes met onder meer opsluiting in paardenstallen en te hard aangesnoerde plastic handboeien: 'Zeventien klachten bij Comité P na betoging 'gele hesjes', Bruzz, 13 december 2018, https:// www.bruzz.be/samenleving/zeventien-klachten-bij-comite-p-na-betoging-gelehesjes-2018-12-13; Lars Bové, 'Politie ging boekje te buiten bij arrestaties van gele hesjes' 29 mei 2020, https://www.tijd.be/politiek-economie/belgie/algemeen/ politie-ging-boekje-te-buiten-bij-arrestaties-van-gele-hesjes/10229839.html. Zie Vast Comité van Toezicht op de politiediensten, Aanbevelingen in geval van grootschalige bestuurlijke aanhoudingen, 2020, 10p. https://comitep.be/document/ onderzoeksrapporten/2020-05-26\%20Recommandations \%20en \%20cas $\% 20$ d'arrestations \%20administratives \%20à \%20grande \%20nl.pdf 
catechismus. ${ }^{19}$ Deze praktijk blijft vandaag voortduren, wat schrijnend tot uiting komt aan de grenzen van de Europese Unie en de VSA, in de hongergebieden van Afrika, in Jemen, in Syrië, en in de disruptie van het klimaat, de droogte, het smelten van de polen, de sprinkhanenplagen, de orkanen en stormen, desertificatie, uitputting van hulpbronnen, het verdwijnen van soorten, en ja natuurlijk, de zoönoses .... Het 'brutalisme' is overal aan zet. ${ }^{20}$ De waanzinnige kloof die er gaapt tussen arm en rijk (264 individuen bezitten meer dan 7 miljard anderen ${ }^{21}$, tussen honger en schaamteloze verspilling, tussen gezondheid en ziekte/dood, tussen perspectief en wanhoop is bovendien verre van een kloof die netjes tussen veilig afgebakende wereldregio's ligt, nee, zij is te vinden in alle democratische rechtsstaten zelf. De trickle down doctrine van de Chicago boys is nonsens: aandeelhouders willen zoveel mogelijk dividenden binnen halen (zelfs als ze op oudere leeftijd, zoals Bill Gates een caritatieve opstoot krijgen en hopen dat het hen wat aflaat zal opleveren). Er zijn geen gelijke kansen, er zijn geen gelijke startsituaties, er zijn geen gelijke vrijheden, en, en hoe men het draait of keert: discriminatie wegens niet genoeg geld is schering en inslag. Zo ontstaan er nieuwe en bijkomende 'raciale' scheidingslijnen of specificaties, vermogenden vs. onvermogenden, mensen met niet onteigenbare private onroerende goederen vs. collectiviteiten waarvan de territoria bloederig kunnen worden ingepalmd en vernietigd, 'mobiele' (handelslui, internationaal congresserende klassen en tropische vakantiegangers met torenhoge ecologische voetafdruk) vs. 'dolende' (vluchtelingen, economische en klimaatmigranten die geld gaan kosten) personen, aan de grenzen welkome filterbare vs. terugstuurbare of deporteerbare onfilterbare mensen, en dus steeds meer discriminatie en bikkelharde uitsluiting, ook binnen de grenzen (asielcentra, gevangenissen, opvangtehuizen, etc.). ${ }^{22}$

Tegen de achtergrond van deze gegevens verschrompelen vele mensenrechtenartikelen tot immateriële afval. Om het met David Graeber te zeggen: 'States have a peculiar dual character. They are at the same time forms of institutionalized raiding or extortion, and utopian projects. The first certainly reflects the way states are actually experienced, by any communities that retain some degree of autonomy; the second however is how they tend to appear in the written record' ${ }^{23}$ Het verhaal van de democratische rechtsstaat

19 R. Patel \& J. Moore, A history of the world in seven cheap things, University of California Press, 2017, 328p.

20 A. Mbembe, Brutalisme, Paris, La Découverte, 2020, 246p.

21 A. Badiou, Trump, Paris, PUF, 2020, 104p.

22 A. Mbembe, Brutalisme, Paris, La Découverte, 2020.

23 D. Graeber, Fragments of an anarchist anthropology, Prickly Paradigm Press, Chicago, 2004, 65. 
heeft dus iets van een utopie, maar eigenaardig genoeg is die utopie al 250 jaar oud, en blijft ze ondanks slavernij, oorlog, foltering, armoede, honger, deportaties, racisme en nog deprimerende hopen meer fraais sterk voortleven. Wat houdt die illusie in stand? ${ }^{24}$ Welke rol spelen de mensenrechten bij het staande houden van deze utopie?

\section{Terug van weggeweest: de herontdekking van universele mensenrechten na de Tweede Wereldoorlog}

Indien de mensenrechten vanuit het argument dat ze door de 'natuur' gegeven zijn in de liberale revoluties en omwentelingen van de $17^{\text {de en }} 18 \mathrm{de}$ plechtig werden geproclameerd, verdwijnen ze als dusdanig, als 'universele rechten', eigenlijk bijzonder snel van het toneel. Daarmee wordt de opstoot van universalisme meteen in de kiem gesmoord. Ze worden voortaan via het positief recht - de grondwet - voorzien voor burgers. Zo bevat de Franse grondwet van 1875 niet eens meer een hoofdstuk over grondrechten, ${ }^{25}$ wat niet alleen sterk contrasteert met hun hoog geproclameerde universalisme in de Déclaration van 1789 maar ook veel beter strookt met de bikkelharde werkelijkheid van de dan nog ruim verspreide slavernij en slavenhandel, het institutioneel racisme, vrouwen zonder rechten, armoede, ziekte, honger, ...

Zo het verhaal van de natuurlijke en onvervreemdbare rechten en vrijheden van de mens een bijzonder welkom en sterk legitimiteitsargument vormde in de strijd tegen de despotische, absolute en arbitraire macht van de vroegere vorsten, blijkt inderdaad zeer snel dat ze ook kunnen ingeroepen worden tegen de liberale bourgeoisie, zeker als ze worden losgekoppeld van eigendom en rijkdom. Dat laatste was ook wat Robespierre en de zijnen beoogden en daadwerkelijk hebben vertaald in wat als 'de terreur' de geschiedenis is ingegaan. Daarom vallen de rechten van de mens ook snel in ongenade bij sommige belangrijke liberale denkers zoals Bentham ('nonsense upon stilts') en Say, die net als Locke de bescherming van individuele eigendom zien als een voorwaarde en garantie voor algemene welvaart. In 1795 komt al een einde aan de 'terreur van de mensenrechten' - de chaos en het bloed wordt geweten aan hun niet-bourgeois liberale invulling - en vanaf

24 Wellicht ook de greep op de perceptie van de dingen door haar share- en stakeholders, hun spindoctors en communicatie: 'Nous ne manquons pas de communication, au contraire nous en avons trop, nous manquons de création. Nous manquons de résistance au présent' (G. Deleuze \& F. Guattari, Qu'est-ce que la philosophie ? Éditions de Minuit, Paris, 1991, (206p.), 103-104).

25 Y. Bosc, La terreur des droits de l'homme, Kimé, Paris, 2016, 297p. 
dan, na het einde van de revolutie (Napoleon is aan het broeden) staat de verdere ontwikkeling van de Franse staat in het teken van juist die nederlaag van de droits de l'homme. De Déclaration van 1789 gaat inderdaad bijna tweehonderd jaar in de Franse diepvriezer om in 1971 door toedoen van de Franse Conseil Constitutionnel weer op te duiken in de 'bloc de constitutionnalité'

De mensenrechten worden vanaf 1795 dus iets heel anders: geen grote vanuit de natuur afgeleide quasi-Bijbelse verkondigingen, maar in de wet verwoorde burgerlijke en politieke prerogatieven die de nationale wetgeving erkent, voorwaardelijk maakt en op allerlei manieren beperkt. Het 'natuurrecht' en de politieke filosofie delven het onderspit voor het juridisch positivisme en de realpolitik. ${ }^{26}$ Ergo: voor de niet-eigenaars en onvermogenden gaan ze lange jaren erg weinig tot helemaal niets betekenen. Marx wond er geen doekjes om en zag de geproclameerde mensenrechten als de legitimatie van privileges van de op zichzelf gekeerde en egoïstische bourgeois eigenaar: voor hem zijn ze ideologische mystificatie, schijngelijkheid en holle woorden (o.m. in Sur la question juive, 1843).

In het standaardverhaal over de mensenrechten speelt het midden van de twintigste eeuw een grote rol en dat omdat de stap wordt gezet van nationale mensenrechtenbescherming (zo die al bestond in de rechtsorde van staten) naar internationale mensenrechtenbescherming. Het is inderdaad pas na de shock van de tweede wereldoorlog, anderhalve eeuw later, dat de mensenrechten weer als universele waarden ten tonele verschijnen en wel in het erg zwakke internationaal recht. Dat speelt zich in concreto af in de cenakels van de pas opgerichte Verenigde Naties (die toen bestond uit 49 staten tegen 193 vandaag). Deze wedergeboorte is niettemin hoogst problematisch, en dat om drie redenen: gebrek aan geloofwaardigheid van toenmalige grootmachten, gebrek aan juridische hefbomen in het internationaal recht om individuen te beschermen tegen hun staten en haakse visies op welke mensenrechten moeten worden beschermd. ${ }^{27}$

26 Over het belang van het grondig nalezen van grondwetten, niet-verblind door het sprookje van de liberale democratien, zie G. Frankenberg, Comparative Constitutional Studies Between Magic and Deceit, Edgar Elgar, 2018, 360p.

27 Vooreerst hebben de toenmalige grootmachten geen enkele geloofwaardigheid (en wellicht veel minder dan de revolutionairen uit de $17^{\text {de }}-18^{\text {de }}$ eeuw) als ze hun lippendienst aan het mensenrechtenuniversalisme bewijzen: de Europese staten zijn wereldkampioenen van hun schending in de kolonies, de USSR treedt ze systematisch met de voeten en behandelt grote delen van de bevolking als (slacht)vee, en de VSA hebben hun handen vol met gewelddadige segregatie en apartheid. Vervolgens weet het internationaal recht geheel geen blijf met het universalisme: het is mooi om vanaf nu te doen alsof elke individuele persoon een 'subject' van internationaal recht 
Drie jaar na het einde van WOII komt er een niet zoals aangekondigd een algemeen wereldwijd bindend verdrag maar wel een zeer halfslachtig compromis tot stand dat de reactie van de internationale gemeenschap op de 'barbaarse handelingen' en de 'minachting van de mensenrechten' tijdens de voorbije oorlog ensceneert. Vermits een bindend verdrag onmogelijk blijkt, gaan de $\mathrm{VN}$ nu voor een niet bindende resolutie van de Algemene Vergadering, met name de Universele Verklaring die de 'minimum standaarden' uitzet welke zouden moeten gaan gelden als wereldwijde maatstaf. ${ }^{28}$ De verklaring erkent 65 rechten waaronder niet alleen de min of meer traditionele vrijheidsrechten (geweten, religie, meningsvrijheid, privacy, ...) maar ook sociale grondrechten en rechten voor specifieke categorieën zoals gevangenen en vluchtelingen. Soms tart het alle verbeelding, zoals art. 24: 'Eenieder heeft recht op rust en op eigen vrije tijd, met inbegrip van een redelijke beperking van de arbeidstijd, en op periodieke vakanties met behoud van loon'. Artikel 17 bevat dan weer een compromis tussen de westerse en socialistische visies op productivisme door aan eenieder een recht op eigendom te geven, 'hetzij alleen, hetzij tezamen met anderen' gekoppeld aan een verbod om niet willekeurig van deze eigendom worden beroofd. In de consideransen verschijnt de universele retoriek weer ten tonele, met een heropleving van natuurrechtelijke formuleringen, ditmaal zonder verwijzing naar God: het gaat om de 'erkenning van de inherente waardigheid en van de gelijke en onvervreemdbare rechten van alle leden van de mensengemeenschap' die een 'grondslag is voor de vrijheid, gerechtigheid en vrede in de wereld'. Luidens artikel 1 worden alle mensen vrij en gelijk in waardigheid en rechten geboren en zijn zij begiftigd met verstand en geweten, en behoren ze zich jegens elkander in een geest van broederschap te gedragen. ${ }^{29}$

is geworden, maar juridisch houdt het geen steek, want er bestaat geen enkel juridisch mechanisme om de onderdanen van staten die daarover geen verdragen aangaan en ratificeren enige juridische internationale afdwingbaarheid van hun rechten en vrijheden te garanderen. Dat punt is overigens vandaag de dag nog steeds problematisch, de ettelijke pogingen die werden ondernomen om de internationale gewoonte en het ius cogens daartoe te mobiliseren ten spijt. En tenslotte blijkt dat sommigen bij 'mensenrechten' denken aan de liberale vrijheidsrechten, de burgerlijke en politieke rechten, en anderen dan weer aan gelijkheidsrechten, of sociale, economische en culturele rechten, en nog anderen aan het recht op dekolonisatie en het zelfbeschikkingsrecht van volkeren. Het discours is hol en de consensus is oppervlakkig. Iedereen gelooft in de mensenrechten, of doet alsof, velen spreken van hun ondeelbaarheid, maar in de praktijk is er vooral veel discours, en voor er enige daadkracht nog maar kan blijken, zijn er al schisma's en scholen.

28 Het universalisme hinkt al in de startblokken want het Oostblok, Saoedi-Arabië en Zuid-Afrika onthouden zich al bij de stemming ...

29 Een expliciete verwijzing naar God is niet aan de orde, wel doen de verwoordingen 
De waarde de Universele Verklaring zelf is in de eerste plaats vooral symbolisch en religieus. Haar inspirerende geloofskracht blijkt wel groot, te meten aan de vele verwijzingen naar de tekst in nationale grondwetten en in 300 verdragen en verklaringen over mensenrechten alleen al op het niveau van de VN. Het oorspronkelijke niet-bindende karakter van de Universele Verklaring en de evolutie daarvan in de tijd, ontwikkelt zich tot een belangrijk thema van de internationaalrechtelijke doctrine. De Verklaring krijgt met de tijd meer juridische kracht omdat ze een instrument wordt in een reeks (meer diplomatieke dan juridische) procedures die tegen VN-leden kunnen worden gevoerd die geen specifieke mensenrechtenverdragen hebben geratificeerd: ze wordt gezien als een bindende interpretatie van de moedertekst van de Verenigde Naties (het 1945 Handvest) dat wél een bindend verdrag is. Zo gaan sommige van zijn bepalingen kunnen gebruikt worden ten aanzien van lidstaten die de $\mathrm{VN}$-mensenrechtenverdragen niet hebben geratificeerd. Maar dit mag niet verdoezelen dat het $\mathrm{VN}$-mensenrechten arsenaal à la carte blijft met spelers zoals de Verenigde Staten en China die om geopolitieke redenen handig zoveel als mogelijk niet toetreden. ${ }^{30}$

Ook heeft het lange tijd ontbroken aan expliciet juridisch afdwingbare mensenrechtenmechanismen waar het individu, onder de rechtsmacht van een ratificerende staat, baat aan heeft. Zo duurt in de schoot van de VN nog tot 1976 tot de twee Internationale Convenanten respectievelijk betreffende de Burgerlijke en Politieke rechten (zonder recht op eigendom!) en Economische Sociale en Culturele rechten (met een recht op betaalde vakantie!) in werking treden na hun ratificatie door 35 lidstaten van de $\mathrm{VN}$, met allesbehalve overtuigende controle- en implementatiemechanismen, die, als ze iets kunnen betekenen steeds optioneel zijn en nooit een internationaal

ervan steeds uitschijnen ze geen rechten in het leven roepen, maar vooraf bestaande 'natuur'-rechten bekrachtigen en beschermen. Over pogingen van onder meer de Nederlandse vertegenwoordiging om een verwijzing naar God op te nemen, leze men J. Morsink, The Universal Declaration of Human Rights; Origins, Drafting, and Intent, University of Pennsylvania Press, 1999, 396p. De verwijzing naar 'menselijke waardigheid' in de preambule is trouwens nieuw ten aanzien van de door ons hoger besproken $18^{\mathrm{de}}$-eeuwse teksten.

30 Zie het interactive world dashboard met kleurtjes waarbij duidelijk blijkt dat beide landen onderaan bengelen in termen van ratificaties (//indicators.ohchr.org). Zie over het 'handig' ontwijken door de VS van internationale verplichtingen, ook onder Obama, inzake extraordinary rendition, Nikolas Kyriakou, 'The International Convention for the Protection of All Persons from Enforced Disappearance and Its Contributions to International Human Rights Law, with Specific Reference to Extraordinary Rendition', Melbourne Journal of International Law, 2012, vol. 13(1), 1-38. Meer algemeen L. Hennebel \& A. Van Waeyenberge (eds.), Exceptionnalisme américain et droits de l'homme, Paris, Dalloz, 2009, 364p. 
gerechtshof oprichten. Uiteraard groeit het belang en het gewicht van die verdragen en het werk van hun organen, in het bijzonder van het Human Rights Committee, naarmate meer staten ze ondertekenen, al dan niet met acceptatie van de controlemechanismen, en uiteraard verzetten de $\mathrm{VN}$ een hoop werk via andere mogelijkheden tot en met de vrij recente oprichting van de Human Rights Council. Politieke druk helpt zeker, maar dat verloopt met mondjesmaat en heel erg traag. Staten worden discreet en voorzichtig maar toch met aandrang verzocht om inspanningen te doen, doch dikwijls is het een spel tussen de pot en de ketel die elkaar verwijten zwart te zien, als de mensenrechten al niet worden gebruikt om een andere rekening te presenteren en te vereffenen. Hoe betekenisvol die stappen ook zijn, het blijven druppels op een hete plaat, zeker wat betreft de sociale economische en culturele rechten. De herder in de Kalahari woestijn, de inwoner van de favella's, Dharavi of de Marollen en ga zo maar lang door, voor hen betekenen ze helemaal niets. En voor wie de wereld buiten het Westen wat verkend heeft, vandaag nog heeft het verhaal daar maar bitter weinig effect, als het al geen averechts effect is. Het is in elk geval, zoals de Joods-Christelijke traditie waarbij ze overigens aansluit, een vooral Westerse seculiere religie.

Maar dat doet de $\mathrm{VN}$ niet capituleren, althans sommige lidstaten ervan en zeker de $\mathrm{VN}$-administratie. Er wordt geschaafd aan verdragen, en verdrag na verdrag worden meer en meer ideeën om collectief en individueel toezicht efficiënter te maken geïncorporeerd. ${ }^{31}$ Maar de Europese benchmark van een zetelend Hof dat over individuele klachten veroordelingen kan uitspreken (infra) wordt binnen de $\mathrm{VN}$-structuren niet gehaald, als dit al een streven van de meerderheid van de lidstaten zou belichamen. ${ }^{32}$

31 Het volstaat om de hoofdstukken over toezicht en handhaving te vergelijken van de genoemde 1976 Convenanten met deze in het 1984 Verdrag tegen martelen en 1989 Verdrag inzake de rechten van het kind, en het 2007 Verdrag tegen gewongen verdwijningen. Zie over de innovatieve elementen inzake toezicht mbt het Committee on Enforced Disappearances in het laatstgenoemde verdrag, Nikolas Kyriakou, l.c., 35-36.

32 Soms is het resultaat evenwel niet veraf. De VN heeft mee de schouders gezet onder het Internationaal Strafhof dat sedert de inwerkingtreding van het Statuut van Rome (2002), uitspraak doet over klachten over agressie, genocide, misdaden tegen de menselijkheid of oorlogsmisdaden. Universele rechtsmacht wordt niet voorzien en het Hof is in beginsel alleen maar bevoegd voor klachten betreffende ondertekenende staten, tenzij er tussenkomst is van de VN Veiligheidsraad. Gedwongen verdwijningen vallen onder de rechtsmacht van het Hof, maar zijn aanvullend geregeld in het 2007 Verdrag tegen gedwongen verdwijningen, dat in beginsel alle ondertekenende (65 van de 194) landen verplicht daders van deze misdrijven zelf te vervolgen of hen uit te leveren indien ze dat niet doen én in artikel 9 verplichte universele jurisdictie voorschrijft waardoor het net volledig gesloten wordt. Vgl. Kirsten Anderson, 'How effective is the international Convention for the protection of all persons from enforced disappearance likely to be in holding individuals criminally responsible for 


\section{De vertaling van het universele in het regionale: Amerikaanse en Europese mensenrechtensystemen}

Tegen de achtergrond van de papieren tijger die de Universele Verklaring bleek te worden, ontwikkelen zich regionale initiatieven die een grotere stap willen zetten. De in 1948 opgerichte Organisatie van Amerikaanse Staten (OAS) keurde nog datzelfde jaar (zeven maanden voor de VN Verklaring) een American Declaration of the Rights and Duties of Man goed, met veel aandacht voor tweede generatie of sociaal-economische rechten. Toezicht werd mogelijk gemaakt in 1959 onder de vorm van de Inter-Amerikaanse Commissie voor de Rechten van de Mens, in 1978 aangevuld met het InterAmerikaanse Hof voor de Rechten van de Mens op basis van het Amerikaanse Verdrag inzake de Rechten van de Mens van 1969, dat in 1988 via een aanvullend protocol niet alleen individuele vrijheidsrechten voorziet maar ook economische, sociale en culturele rechten (in werking 1999). Onnodig om daaraan toe te voegen dat Canada en de Verenigde Staten hierbij geen partij zijn.

Ook de Raad van Europa wou sneller en verder gaan dan de verdeelde $\mathrm{VN}$ en formuleerde een bindend Europees Verdrag voor de Rechten van de Mens (1950) dat zich beperkt tot een 20 -tal afweerrechten of eerste generatie rechten, doch wel een Europees toezichtshof voorziet, het Europees Hof voor de Rechten van de Mens (EHRM). Het succes van het EVRM is gekend en alom geroemd. Toen het Hof eenmaal aan de slag ging (1959) was de sfeer optimistisch, met een nog bloeiende welvaartstaat die ons zowel de golden sixties en de baby boomers (zoals Sonja) na zou laten.

Met het wegsnijden van de sociaal-economische rechten en het vervolgens stiefmoederlijk opvangen ervan in tandeloze teksten zoals het Europees Sociaal Charter van $1961^{33}$ heeft Europa zeker een snelle start genomen inzake

acts of enforced disappearance?', Melbourne Journal of International Law, 2006, vol $7(2),(245-278), 275$ : 'This could be preferable to relying on an international tribunal to prosecute enforced disappearances as 'juridical norms of protection of the individual are much more effective when they are integrated into domestic law' ... The duty to prosecute or extradite works together with the principle of universal jurisdiction to prevent states from operating as 'safe havens' for perpetrators'.

33 De zwakte van het Charter heeft niets verwonderlijks en is natuurlijk een gevolg van het feit dat het voor een staat gemakkelijker is om zich te engageren zich in principe niet in te mengen in erkende vrijheden (al hebben de leerstukken van de positieve verplichtingen en de horizontale werking dat onthoudingsprincipe behoorlijk genuanceerd) dan zich te verbinden om het nodige te doen opdat mensen hun rechten op onderwijs, arbeid, gezondheid, woning en voeding gegarandeerd zouden zien. En wellicht kon men zich toen niet inbeelden dat Thatcher en Reagan, laat staan Trump, Johnson en Poetin, ooit touwen in handen zouden krijgen om de democratische 
liberale vrijheidsrechten. Toch blijkt vandaag in een tijdperk met beduidend minder sociale rechtvaardigheid des te schrijnender het gebrek aan een krachtig mechanisme voor afdwinging van sociaal-economische rechten, en dit ondanks de hervormingspogingen van het Charter in 1991, 1995 en 1996 om een rapportage systeem aan te vullen met een systeem van collectieve klachten dat ons land (pas) in 2003 bekrachtigde. ${ }^{34}$ De zwakke afdwingbaarheid van deze 'Social Constitution of Europe' en de veranderende sociaaleconomische context van vandaag steken sterk af tegen het breed scala aan opgesomde grondrechten op het gebied van werkgelegenheid, huisvesting, gezondheid, onderwijs, sociale bescherming en welzijn, met aandacht voor kwetsbare personen zoals ouderen, kinderen, mensen met een handicap en migranten. Het herijkte Charter heeft een institutioneel belang, ${ }^{35}$ een eigen werking met actoren die de weg vinden naar de European Committee of Social Rights dat op de naleving naziet, maar het is in maatschappelijke en sociaal-economische discussies zelden een referentiepunt, wat ongetwijfeld ook te maken heeft met het gebrek aan juridisch afdwingbaarheid. Zo misten we in het 2020 COVID-debat discussies gevoerd in termen van sociale rechten, terwijl discussies over bijvoorbeeld politie wel degelijk gevoerd werden in termen van eerste generatierechten zoals meningsvrijheid en privacy. Dat brengt ons terug bij het succesvolle EVRM en het EHRM, die wel frequent aangehaald wordt in maatschappelijke en juridische discussies.

In de preambule van het EVRM bevestigt de Raad van Europa, met verwijzing naar de UVRM, zijn 'diep geloof (...) in deze fundamentele vrijheden die de grondslag vormen voor gerechtigheid en vrede in de wereld en welker handhaving vooral steunt, enerzijds op een waarlijk democratische regeringsvorm, anderzijds op het gemeenschappelijk begrip en de gemeenschappelijke eerbiediging van de rechten van de mens waarvan die vrijheden afhankelijk zijn'. De retoriek is in vergelijking met de VN Verklaring van 1948 lichtjes verschillend. De pendel schuift, in lijn met de $18^{\text {de }}$ eeuwse denkwereld, weer richting 'vrijheid' ten nadele van de in 1948 even opgeborrelde 'menselijke waardigheid'. ${ }^{36}$ De seculiere geloofsbelijdenis in het,

rechtsstaat geheel uit te hollen en over te leveren aan de captains of industry door alle negatieve gevolgen van het groei-kapitalisme brutaal te externaliseren op het conto van sociaal welzijn, sociale zekerheid, milieu, cultuur, gezondheid, enzovoort. Zo de teksten nog beleden mogen worden, zijn tweede generatie rechten juridisch gesproken losse flodders waarrond de staten naar best inzicht beleid of 'on'beleid voeren.

34 https://www.coe.int/en/web/european-social-charter/about-the-charter.

35 Haar bepalingen zijn door de Europese Unie overgenomen en tezamen met de eerste generatie rechten gegoten in het EU-Handvest van de grondrechten (2000) dat in 2009 bindend werd (infra).

36 Het is slechts in de 2002, in de preambule van protocol 13 ter afschaffing van de 
superieur geacht Westers politiek systeem is deze keer helemaal expliciet en omvat meteen ook de 'waarlijk democratische regeringsvorm', wat ook strookt met de doelstellingen van de Raad van Europa, met name de politieke eenmaking van een democratisch rechtsstatelijk Europa. In dat verband 'steekt' het dat de maatschappelijke en politieke participatierechten die we aantreffen in de $1948 \mathrm{VN}$ Verklaring niet of nauwelijks zijn overgenomen (rechten op deelname aan het bestuur van een land, het recht te kiezen en gekozen te worden in algemene geheime verkiezingen, gelijke rechten op openbare functies, gelijke kiesrechten voor man en vrouw en het recht op nationaliteit). We komen, na een korte uiteenzetting over een tweede en veel jongere Europees mensenrechten-pijler, onmiddellijk terug op wat het EVRM wel te zeggen heeft.

Sinds de jaren '70 gaan de mensenrechten ook in het EU-recht binnensijpelen, al gebeurt dit in de eerste plaats via de rechtspraak van het Hof van Justitie dat ze gaat beschouwen als een inherent onderdeel van de algemene rechtsbeginselen die het moet handhaven. Het Luxemburgse Hof verwijst daarbij ook naar Straatsburgse arresten (wat op zich een garantie kan zijn voor eenvormigheid doch mogelijkheid tot tegenstrijdige en moeilijk te articuleren uitspraken is niet uitgesloten). Tevens vindt binnen de EU een constitutionalisering van de mensenrechten plaats wanneer het Charter van de Fundamentele Rechten van de Unie (2000), oorspronkelijk soft law, wordt opgenomen in het Unieverdrag (art. 6, 1) en sedert 2009 daardoor bindend wordt (ondanks tegenstand van landen zoals Polen en het Verenigd Koninkrijk die van géén bindende directe werking willen). ${ }^{37}$

Met het EU-Charter wordt het natuurrechtelijke verhaal weer opgevist, maar de pendel gaat weer richting 'menselijke waardigheid' vallen. Immers de EU is 'bewust van haar geestelijke en morele erfgoed (en) vestigt (...) haar grondslag op de ondeelbare en universele waarden van menselijke waardigheid en van vrijheid, gelijkheid en solidariteit' ( $2^{\text {de }}$ considerans). Er komt een 'innoverend' art. 1 met volgende boodschap: 'De menselijke waardigheid is onschendbaar. Zij moet worden geëerbiedigd en beschermd'. ${ }^{38}$

doodstraf, dat de 'inherente menselijke waardigheid' in het EVRM-kader ten tonele zal verschijnen.

37 De toetreding van de EU tot de Raad van Europa en het EVRM worden ook voorzien, maar wordt, niettegenstaande alles in gereedheid werd gebracht, op 18 december 2014 door een voltallig en unaniem HvJ in advies 2/13 gekelderd. Dat heeft natuurlijk veel te maken heeft met wie nu het laatste woord zal hebben, Straatsburg of Luxemburg, een inzet die weer duidelijk maakt dat er veel speling en zelfs spanning zit op wat de abstracte geloofsbelijdenis in concreto kan gaan betekenen.

38 Wat hier gebeurt is o.i. nog steeds te weinig gedocumenteerd. Vrijheid, gelijkheid, waardigheid... het zijn evenzoveel kernwaarden van waaruit de mensenrechten 
Het EU Charter somt een 50tal rechten en vrijheden op die het resultaat zijn van het copy-pasten uit het EVRM, het Europees Sociaal Charter van 1961 en een reeks andere verdragen, aangevuld ook met nieuwe rechten. In de mate dat dit zinvol is voor een regionale supranationale organisatie, gegroeid uit een project van economische eenmaking van een regionale markt, wordt het principe van universaliteit weer geponeerd, net als de daaraan verwante principes van ondeelbaarheid, onderlinge afhankelijkheid en onderlinge verwevenheid van mensenrechten ${ }^{39}$. Het gemak waarmee deze 'constitutionele' oefening werd gemaakt blijft verbazen, tenzij men aandachtig kijkt naar de achtergrond en mentale disposities van de transnationale gemeenschap die de tekst heeft opgesteld. ${ }^{40}$ Opvallend ook zijn de zorgvuldig getoonzette rechten op ondernemerschap en eigendom, rechten die in het

kunnen gedacht worden. Om de Duitse kritiek op een Unie zonder grondrechten te pareren heeft men bij de opstelling ervan, het openingsartikel van de Duitse Grondwet gekopieerd dat kiest voor menselijke waardigheid als de moeder aller mensenrechten. Men leze P. De Hert, 'John Rawls on Constitutionalism and the Charter of Fundamental Rights of the European Union', in W.P. Heere (ed.), From Government to Governance. The Growing Impact of Non-State Actors on the International and European Legal System, Proceedings of the Sixth Hague Joint Conference held in The Hague, The Netherlands on 3-5 July 2003, Den Haag, TCM Asser Press, 2004, 443-453. Wat de meerwaarde is van dit funderingselement in de EU-orde, is nog steeds niet helemaal duidelijk, maar dat je waardigheid, in tegenstelling tot vrijheid, positief moet kunnen omschrijven (wat is waardig, wat niet?), stelt mooie theologische disputen in het vooruitzicht, waarbij de oorspronkelijke liberale vrijheid onder druk komt te staan van conservatief (of zelfs 'links politiek correct') moralisme en paternalisme die via 'Het Menselijk Waardige' worden binnengesmokkeld. De ervaringen met de persoonlijkheidsrechten, een soort privaatrechtelijke mededinger van de publiekrechtelijke mensenrechten, in Duitsland, Frankrijk en Italië laten daaromtrent weinig illusies toe (F. Rigaux, La protection de la vie privée et des autres biens de la personnalité, Bruylant/LGDJ, Bruxelles/Paris, 1990, 849p.).

39 Cf. de Verklaring van Wenen van 1993 van de Verenigde Naties, waarin onder meer wordt geaffirmeerd en herinnerd dat sociale rechten mensenrechten zijn op gelijke voet met burgerlijke en politieke rechten.

40 Over deze 'transnational community of politico-legal experts-entrepreneurs', leze men Antonin Cohen, 'Legal Professionals or Political Entrepreneurs? Constitution Making as a Process of Social Construction and Political Mobilization', International Political Sociology, 2010, 4, 107-123; Vgl. 'In the light of this prosopographical data, it can be hypothesized that the much-commented consensus method at the Convention may have had, as an unspoken prerequisite, a coalition of pre-existing social dispositions that went far beyond the formal institutional divides (widely transcended by a set of trajectories crossing the boarders of the national and the supranational), and traditional political cleavages (considerably reduced by the concentration of party representation), both constrained by the fact that the Praesidium and particularly the President succeeded in exercising a firm control over the agenda' (p. 119). 
EVRM veel minder zichtbaar zijn, wat natuurlijk niet moet verwonderen in het licht van de genealogie van de EU. ${ }^{41}$

\section{De performantie van het EVRM en Europees Hof voor de Rechten van de Mens (EHRM) te Straatsburg}

\section{Terug naar het EVRM en het EHRM dat erop toeziet. In haar werk besteed} Sonja Snacken uitvoerig aandacht aan de rechtspraak van het Hof en de mogelijkheden om detentieregimes te herdenken. Het intellectuele gemak waarmee dat doel kan bereikt worden aan de hand van de Europese rechtspraak, brengt haar af en toe dicht bij een geloof in de compleetheid van het verhaal van de mensenrechten als basis voor hervorming en beleid, meer nog dan de optelsom van klassieke penologische theorieën. Daarbij speelt natuurlijk dat het Hof stilaan meer inspiratie puurt uit het preventieve terreinwerk, waarbij zij betrokken is, van het Committee for the Prevention of Torture dat, vanuit een doorleefde ervaring met fundamentele rechten en vrijheden in plaatsen van detentie, vooral gerichte en soms meer algemene aanbevelingen geeft.

Vanuit onze vertrouwdheid met de Europese mensenrechtenrechtspraak over politie kunnen we dat goed begrijpen: de impact van het EVRM op politiepraktijken is tastbaar (al is het in tijden van Black Life Matters duidelijk dat er nog heel veel werk voor de boeg is, ook in Belgenland). Doordat het EVRM directe werking heeft in de nationale Belgische rechtsorde, oefent de Straatsburgse rechtspraak een belangrijke juridische invloed uit op die problematiek. ${ }^{42}$ De politie komt aan bod in veel uitspraken van het EHRM, en

41 Cf. Artikel 16 Vrijheid van ondernemerschap ('De vrijheid van ondernemerschap wordt erkend overeenkomstig het Unierecht en de nationale wetgevingen en praktijken'); artikel 17 Recht op eigendom ('1. Eenieder heeft het recht de goederen die hij rechtmatig heeft verkregen in eigendom te bezitten, te gebruiken, erover te beschikken en te vermaken. Aan niemand mag zijn eigendom worden ontnomen, behalve in het algemeen belang in de gevallen en onder de voorwaarden waarin de wet voorziet en mits zijn verlies tijdig op billijke wijze wordt vergoed. Het gebruik van de goederen kan worden geregeld bij de wet voorzover het algemeen belang dit vereist. 2. Intellectueel eigendom is beschermd').

42 Zie ook P. De Hert, 'Voor wie ze soms geweld aandoen. Politie en mensenrechten' in G. Duhaut, P. Ponsaers, G. Pyl \& R. Van De Sompel (eds.), Voor verder onderzoek. Essays over de politie en haar rol in onze samenleving. - Poursuite d'enquête. Essais sur la police et son rôle dans notre société, Brussel, Politeia, 2002, 75-102; P. De Hert, 'Politie en mensenrechten: meer ethiek a.u.b. want te weinig recht', in C.J.C.F. Fijnaut, E.R. Muller, U. Rosenthal \& E.J. Van De Torre (eds.), Politie. Studies over haar werking en organisatie, Deventer, Kluwer, 2007, 601-654; P. De Hert, 'Politie en mensenrechtent', in E.R. Muller, E.J. Van De Torre, A.B. Hoogenboom \& N. Kop (eds.), Politie. Studies over haar werking en organisatie, Deventer, Kluwer, 2014, 353-408. 
dat verwondert niet. Het optreden van ordediensten en politieacties raakt bij nader inzien meerdere individuele mensenrechten beschermd door het EVRM. Zo moet gebruik van (potentieel) dodelijk geweld door politie de toetsing van art. 2 EVRM (recht op leven) kunnen doorstaan. Politiehandelingen kunnen ook aan art. 3 EVRM raken (verbod van foltering, mensonwaardige of vernederende behandelingen of bestraffing). België werd in 2015 op de vingers getikt door de Grote Kamer van het Europees Hof in Bouyid ${ }^{43}$ naar aanleiding van aantijgingen dat personen in een Brussels politiekantoor door agenten in het aangezicht waren geslagen. Hoe politie de orde handhaaft tijdens (politieke en andere) manifestaties of publieke bijeenkomsten, moet eveneens de toetsing van het EVRM kunnen doorstaan. S., V., en A./Denemarken bekijkt politieoptreden bij voetbalmanifestaties in het licht van art. 5 EVRM (recht op vrijheid en veiligheid) en het verbod op onrechtmatige vrijheidsberoving ${ }^{44}$. Ook art. 6 EVRM (recht op een eerlijk proces) heeft gevolgen voor politie met een werking die verder reikt dan louter de procedure voor de rechtbank. Salduz ${ }^{45}$, Brusco $^{46}$ en daaropvolgende rechtspraak rond het recht op bijstand van een advocaat en het zwijgrecht tijdens het vooronderzoek in strafzaken leidde tot diepgaande wijzigingen in het nationaal recht, een evolutie die, ook bij ons, nog steeds gaande is. ${ }^{47}$ Ook onderzoeksmaatregelen zoals surveillering, zoekingen, en inbeslagnames moeten de toets van Straatsburg kunnen trotseren. Hierbij speelt art. 8 EVRM (eerbiediging van privé-, familie- en gezinsleven, woning, en correspondentie) een voorname maar niet-exclusieve rol. Politieacties kunnen verder in conflict treden met art. 9 (vrijheid van gedachte, geweten en godsdienst), art. 10 (vrijheid van meningsuiting), en art. 11 EVRM (vrijheid van vergadering en vereniging). En indien de overheid door het verdrag geoorloofde beperkingen hanteert tot nastreving van een niet-legitiem doel (bijvoorbeeld om politieke protesten monddood te maken), dan kan dit vragen oproepen in het licht van art. 13 EVRM (verbod op machtsafwending) in

43 EHRM 28 september 2015 (Grote Kamer; GK), nr. 23380/09, Bouyid/België.

44 EHRM 22 oktober 2018 (GK), nrs. 35553/12, 36678/12 en 36711/12, S., V., en A./ Denemarken. In een arrest waarin het Hof zijn rechtspraak rond art. 5, $\$ 1$ (c) EVRM in dit kader evolueerde, achtte het het plaatsen van een tijdelijk preventief cordon rond voetbalsupporters een geoorloofde vrijheidsberoving.

45 EHRM 27 november 2008 (GK), nr. 36391/02, Salduz/Turkije.

46 EHRM 14 oktober 2010, nr. 1466/07, Brusco/Frankrijk.

47 Zie recent EHRM 9 november 2018 (GK), nr. 71409/10, Beuze/België - Schending van art. 6, $\$ \$ 1$ and 3 (c) EVRM. Noot van J. Huysmans, 'Het recht op bijstand van een advocaat bij het verhoor: een ruim maar relatief recht', $P \& R 2020$, nr. 1, 40-52; M-A. Beernaert, 'Droit d'accès à un avocat et relativité toujours plus grande des garanties du droit à un procès équitable’, RTDH 2019, nr. 118, 519-528. 
samenlezing met één of meerdere van de voornoemde verdragsbepalingen. Ook het niet-optreden door ordediensten kan de bepalingen van het EVRM tot leven wekken. Dit omdat deze niet alleen een negatieve implicatie voor lidstaten inhouden - namelijk niets doen in strijd met deze Europese vereisten - maar ook een positieve verplichting. De overheid moet individuen namelijk ook beschermen tegen een aantasting van hun mensenrechten door derden, want de verdragsbepalingen hebben ook een horizontale werking. ${ }^{48}$ Recente rechtspraak illustreerde reeds hoe het niets doen door ordediensten in strijd met het EVRM kan zijn, met name wanneer tegenbetogers agressief te keer gaan tegen betogers, of terwijl manifestanten personen waartegen zij protest uiten te lijf gaan. ${ }^{49}$ Ook een verbod om te betogen moet aan de Europese voorwaarden voldoen. Indien een manifestatie wordt uiteengedreven of bestraft, louter omdat er op voorhand geen toelating voor de bijeenkomst werd gevraagd, kan dit te ver gaan voor de Straatsburgse rechters.

Zonder enige twijfel zijn het EVRM en het EHRM de veruiterlijking van 's werelds meest performante juridisch mechanisme voor de afdwinging fundamentele vrijheden en rechten in bepaalde al dan niet generische situaties waarbij de Raad van Europa de politieke waakhond van de follow up door de verdragstaten is. De Amerikaan Michael Goldhaber schreef in 2007 een boekje over het Hof waarmee hij ten behoeve van een Amerikaans publiek ingaat op deze 'juridische arm van de Raad van Europa'..$^{50}$ De auteur verwondert zich erover dat iedereen vertrouwd is met de belangrijke mensenrechtenrechtspraak van het Amerikaanse Hooggerechtshof uit de jaren 1960-1970, maar veel minder met het EHRM dat op 30jaar tijd een ambitieuze en vergelijkbare rechtspraak heeft ontwikkeld. Dit obscure tribunaal in Straatsburg, Frankrijk, werd door de massapers niet in het licht gezet, terwijl het volgens de auteur een Supreme Court of Europe is geworden dat het aandurft lidstaten terug te fluiten zelfs in zeer delicate onderwerpen. Het boek illustreert dat met talloze voorbeelden zoals de abortusrechtspraak die Ierland pijn heeft gedaan, de religierechtspraak die Griekenland en zijn trouw aan de Griekse orthodoxie pijn heeft gedaan, Turkije over Koerdisch separatisme; Oostenrijk over het nazisme; en Groot-Brittannië over homorechten

48 Men leze T. Decaigny, 'Positieve mensenrechtenverplichtingen met betrekking tot politie en justitie. Verduidelijking aan de hand van Europese rechtspraak over intrafamiliaal geweld en seksueel misbruik', T. Strafr. 2012, nr. 1, 3-16.

49 Vergelijk bijvoorbeeld EHRM 12 mei 2015, nr. 73235/12, Identoba e.a./Georgië (schending van art. 3, 11 en 14 EVRM) met EHRM 24 februari 2015, nr. 30587/13, Karaahmed/Bulgarije (schending van art. 9 EVRM).

50 Michael Goldhaber, A People's History of the European Court of Human Rights, Rutgers University Press, 2007, 210p. 
en lijfstraffen. Het boek begint met een hoofdstuk over een 'bastaard'-kind, Alendra Marckx, vertegenwoordigd door ongetrouwde moeder Paula Marckx, die in het katholiek conservatieve burgerlijk wetboek van België hebben doen daveren en de weg hebben vrijgemaakt voor een familierecht waarin niet-trouwen een erkende vrijheid is. ${ }^{51}$ Hoewel we vele tegenvoorbeelden van kwestieuze en onderling incompatibele beslissingen kunnen geven, ${ }^{52}$ begrijpen we Goldhaber's positieve indruk over het Europees Hof dat hij in zijn Concluding thoughts een ereplaats geeft in de strijd om het geweten van de wereld te zijn. Wij vinden het vanuit ons perspectief vooral positief dat het Hof bestaande problemen en issues in een goede richting helpt evolueren; dat 'geweten van de wereld' moeten we niet: de toekomst is open, ook het geweten kan en moet die niet vormgeven en opvullen.

Het Europees Hof is overigens geen grondwettelijk hof omdat het geen vernietigingsbevoegdheid heeft en subsidiair is aan de nationale juridische bescherming ('na de uitputting van nationale rechtsmiddelen'); haar inschuiving in de nationale normen hiërarchie verschilt overigens van lidstaat tot lidstaat en de afdwingbaarheid van zijn arresten door de Raad van Europa is

51 Over de moed van de onlangs overleden Paula Marckx, leze men Laurens Lavrysen, 'Remembering Paula Marckx' 1 juli 2020, via https://strasbourgobservers. com/2020/07/01/remembering-paula-marckx/

52 Sonja Snacken heeft zich er terecht aan gestoord dat de Straatsburgse rechters aanvaarden dat de gevangenisstraf een inherente dosis vernedering met zich meedraagt. Anderen vielen achterover wanneer het Hof, in Khan, besliste dat een schending van het strafprocesrecht nog niet moest leiden tot de uitsluiting van onrechtmatig verkregen bewijs (P. De Hert \& S. Gutwirth, 'Over de betekenis van strafprocedurele grondrechten in het post-Khan tijdperk' in A.H.E.C. Jordaans, P.A.M. Mevis \& J. Wöretshofer (eds), Praktisch strafrecht. Liber amicorum J.M. Reijntjes, Wolf Legal Publishers, Nijmegen, 2005, 213-232; P. De Hert \& E.-J. Koops, 'Privacy is nog steeds een grondrecht. Pleidooi voor de uitsluiting van onrechtmatig bewijs', Ars Aequi, 2001, december, (vol. 50), 972-975). Zo zien we ook in dat het Hof in Jersild racistische uitlatingen beschermt onder vrije meningsuiting, terwijl het (weliswaar in een andere samenstelling) in Otto Preminger de privé-vertoning van een blasfemisch geachte film laat verbieden. Met drie dagen verschil tussen de twee uitspraken. Zo stelt hetzelfde Hof in Laskey dat masochistische seksualiteit mag gestraft worden omwille van zijn morele onaanvaardbaarheid en onwaardigheid (en dus dat het masochistische verlangen moet worden ontkend) terwijl het 8 jaar later in $K$.A. met geen woord rept over moraliteit (en over Laskey) en laat verstaan dat er geen probleem is met masochistische seksualiteit zolang het respect van de toestemming van het 'slachtoffer' wordt gerespecteerd. In de laatste twee zaken wordt ook duidelijk wat het verschil is tussen een vrijheidsbenadering en een benadering in termen van 'menselijke waardigheid': in het eerste geval telt alleen het al dan niet conflictueuze karakter van de relaties, in het tweede de morele overtuiging of walging van de rechter(s) die verheven wordt tot universele norm. Geeft men aan de mensenrechters de mogelijkheid om uitspraken te doen op basis van 'menselijke waardigheid' dan loert hun moralisme en paternalisme om de hoek. 
ondermaats. ${ }^{53} \mathrm{Na}$ de ineenstorting van het Oostblok verandert het gelaat van de Raad van Europa en verdubbelt het aantal lidstaten en EVRM-verdragstaten omdat ratificatie van het EVRM voor de toetreding een voorwaarde is geworden. De Raad van Europa bestaat thans uit 47 landen waarvan 27 die lid zijn van de Europese Unie. Met deze aangroei, zeker met mensenrechtenkampioenen als Rusland en Turkije, stijgt niet alleen de werklast van het Hof exponentieel, maar ook de weerstand tegen haar 'activisme' en liberalisme. Conservatieve beslissingen zijn dan ook legio (geworden), vrijheidsbeperkende maatregelen worden nogal gemakkelijk aanvaard en thans staat protocol 16 op de rol, waarin het Hof netjes terug op haar plaats zal gezet worden door een verdragsrechtelijke bekrachtiging van enerzijds de subsidiariteit van het internationaalrechtelijke controlemechanisme en anderzijds de doctrine van de 'margin of appreciation', die stelt dat de staten zelf beter de nationale situatie, mentaliteit en gebruiken kunnen inschatten en dat het Hof zich daarmee dus niet moet inlaten. Dat is natuurlijk weer een knauw voor het 'universalistische' geloof, want het betekent net zoveel dat hoofddoeken in Turkije iets anders zijn dan hoofddoeken in Nederland, om maar te zwijgen over een kwestie als abortus of het respect van fundamentele rechten in plaatsen van opsluiting ... Op zich is dit contextualiseren natuurlijk niet fout, maar hier betekent die een zeer reëel-politieke retour en force van de staatssoevereiniteit en geen verfijning van de rechtspraak.

\section{Korte tussenbalans: mensenrechten als kern van de religie}

In het voorgaande zijn verschillende aanzetten gegeven tot een discussie over het belang van de grondrechten. Het gemak waarmee grondrechten worden 'verklaard', weggeschreven wanneer het erop aankomt of moeizaam (her)ingevoerd en de duidelijke greep van de statenpolitiek op regionale mensenrechtenhoven, doen vragen rijzen over het constituerend belang en continuïteit van grondrechten in Westerse systemen. Gekend is Samuel Moyn's verpletterende deconstructie van die Last Utopia. ${ }^{54}$ Of het verhaal nu teruggaat naar de Grieken of naar de Amerikaanse of Franse revolutie, aldus Moyn, er is weinig verband met ons hedendaags begrip van mensenrechten en in de discussies was er al helemaal geen sprake van een

53 Vgl. 'Scrutiny yes, consequences no' in Kl. Brummer, 'Enhancing intergovernmentalism: the Council of Europe and human rights', The International Journal of Human Rights, 2020, vol. 14/2, (280-299), 282

54 Samuel Moyn, The Last Utopia. Human Rights in History, Harvard, HUP, 2010, 352p. 
mensenrechtenargumentatie. Ook naar aanleiding van de holocaust was er nauwelijks een discussie in termen van mensenrechten, dus ook dat was volgens hem een valse start. De echte start van ons hedendaags mensenrechtenverhaal situeert zich, aldus Moyn, eind jaren zestig toen meer en meer mensen zich ernaar keerde bij verlies aan vertrouwen in alternatieve geloofsssystemen zoals het marxisme en maoisme. Het is in die periode dat mensenrechtenorganisaties zoals Amnesty een bloei kenden en dat politici het verhaal gingen oppikken. ${ }^{55}$ De grote doorbraak kwam er met de Amerikaanse president Carter die van human rights een pijler van zijn beleid (19771981) maakte. 250 jaren grondrechten blijken bij zijn hertelling er maar 50 te zijn ...

Hoewel burgers, volgens tellingen van betrokken instellingen, vandaag nog veel vertrouwen blijken te hebben in het verhaal van de mensenrechten ${ }^{56}$ is de politieke steun ervoor aan het afbrokkelen. Door slechts spaarzaam in te werken op het functioneren van de politiek en de markt en mensenrechtelijk ongemoeid te laten, is een positie van onaantastbaarheid en suprematie niet realistisch. Duidelijk is dat mensenrechten na Wereldoorlog II een finale arbiter functie gaan vervullen, bij gebrek aan beters (God?) wellicht, maar ook door toedoen van de oprichting van constitutionele hoven in de vele staten waar die er nog niet waren. In 1945 vond immers omslag plaats in de zin dat het positivisme van de wet, zeker na te veel jaren Nazi-wetgeving, haar pluimen verloor en geheel manipuleerbaar bleek. De wet als dusdanig is even gevaarlijk als ontspoorde meerderheden. Achter de wet moet er bijgevolg wel iets nog belangrijkers bestaan waaraan ook soevereine wetgevers zich moeten onderwerpen. De Joods-Christelijke traditie en de liberale politieke filosofie, allebei Westers, komen dan samen terecht bij de onvervreemdbare natuurlijke rechten en vrijheden van de mens die afgeleid kunnen worden zowel van het bijbelse 'de mens als evenbeeld van God' als van de politiek-filosofische parabel van de 'natuurstaat', zij het dan met respectievelijk een accent op 'menselijke waardigheid' of op 'vrijheid'. Voor François Rigaux wijst dit erop dat ze een seculiere religie zijn. ${ }^{57}$ Kant was wellicht de laatste grote

55 Over de 'visionary' steun van de Australische Gough Whitlam Labor regering (1972-1975) aan de idee van universele mensenrechten, zie Adam Hughes Henry, 'Gough Whitlam and the politics of universal human rights', The International Journal of Human Rights, 2020, vol 24(6), 796-827.

56 EU Agency for Fundamental Rights (FRA), Many Europeans believe human rights can build a fairer society but challenges remain, press release 24 juni 2020 (met een bespreking van het rapport 'What do fundamental rights mean for people in the EU?' dat aantoont dat $88 \%$ van de EU burgers nog steeds in het verhaal gelooft).

57 «L'idéologie libérale des rapports entre le juge et le législateur a ramené ceux-ci dans le giron d'une religiosité séculière dont les témoins les plus véridiques, parce que les 
Westerse denker die God zag als beschermer van de fundamentele ethische principes en sociale spelregels vertrouwde. ${ }^{58} \mathrm{Na}$ pogingen om de 'Rede' of een 'wetenschappelijke visie op de wereld' (evidence based 'politiek') op die plaats te zetten, zijn het vandaag vooral de 'wetten van de markt', de 'groei' en de 'productiviteit' die ze hebben ingenomen. Gezien de historische ontwikkeling van het kapitalisme, geheel logisch overigens. Ook Harari in Sapiens aarzelt niet om mensenrechten en humanistische theorieën als moderne religies te beschouwen die morgen als verhaal uitverteld kunnen geraken om te worden ingelost door andere verhalen. Deze auteur identificeert drie rivaliserende sekten binnen het humanisme, die alle drie vertrekken van de unieke natuur van de mens; de op het individualisme georiënteerde liberale humanisten, de meer collectivistisch gerichte socialistische humanisten en de evolutionaire humanisten met de Nazi's en hun geloof in een superieur ras op kop. ${ }^{59}$ Het individualisme, dat zo centraal is voor de mensenrechten, is in historisch opzicht niet meer dan een verbond geweest van staten en markt om de hinderlijke macht te breken van familie, gemeenschap en de commons, en alles wat bottom-up politiek dreigt mogelijk te maken. ${ }^{60}$

Er valt iets te zeggen voor mensenrechten als een opgebouwd verhaal dat morgen kan gedumpt worden wanneer aantrekkelijkere verhalen naar

plus naïfs, doivent être cherchés dans le XIXe siècle triomphant, tels Francis Lieber qui affirme : «Un pouvoir judiciaire qui est placé sous la loi... est un membre d'une immense Église, l'Église de la loi» ou le procureur général Mesdach de Ter Kiele qui ouvre les travaux de la Cour de cassation de Belgique à l'audience solennelle de rentrée du 15 octobre 1886 par cette déclaration : «La loi est la vérité suprême par excellence et se confond avec elle [...]. La méconnaître serait une impiété. » À pareille sacralité de la loi, jointe à la sainteté conférée aux prêtres du culte nouveau, a succédé aujourd'hui la religion des droits de l'homme.» (F. Rigaux, La loi des juges, Odile Jacob, Paris, 1997, 284).

58 F. Rigaux, La loi des juges, Odile Jacob, Paris, 1997, 320p. Over de religieuze fundering van Locke's politieke theorie, leze men Greg Forster, John Locke's Politics of Moral Consensus, Cambridge: CUP, 2005, 328p.

59 Yuval Noah Harari, Sapiens. A Brief History of Mankind, Penguin Random House, 2011, 256-258. Fijntjes merkt deze historicus op dat de laatste strekking min of meer gemeengoed was in het Westen van de 1930s en in 1945 'even' van het voorfront moest wijken door het door de Nazi's opgebouwde diskrediet maar morgen terug een eersterangs rol kan spelen, zeker in het licht van onze obsessie met genoom verbetering en ons streven naar intelligente machines die vragen oproepen over het begrip 'mens' (p. 458).

60 Yuval Noah Harari, ibid., 401-403. Deze analyse moet samengelezen worden met de pagina's 410-412 waarin Harari, op basis van cijfermateriaal, stelt dat staten gezorgd hebben voor veel minder geweld en meer vrede dan onder samenlevingen gebaseerd op familie- en gemeenschapsverbonden. 
voren treden. Dat eeuwen geschiedenis van slavernij, kolonisatie, uitbuiting, racisme en discriminatie hebben geleid tot een door het Westen gesponsorde boost van het mensenrechtengeloof en -discours, heeft wellicht te maken met het feit dat een luid discours de verhulling van praktijken in de hand werkt. Foucault heeft hierover veel geschreven, en het is duidelijk dat het verlichtingsverhaal al van in het begin gepaard gaat met machtspraktijken van disciplinering, controle en surveillance, die het tot op het bot uithollen, tenzij je aan de Bezos-Zuckerberg kant van de samenleving bent geboren of erin bent 'opgeklommen'. Het zegt natuurlijk veel over de diepgang en werkelijkheid van de mensenrechtenbewustwording indien die niet gestoord wordt door de eindeloze economische verderzetting van de kolonisatie en het structureel racisme dat erin is ingeworteld, de honger (terwijl wij sterven aan vet), de verwoesting van het habitat van miljoenen, de verdronken kinderen in de Middellandse zee en het sterven van hopen mensen die eigenlijk gemakkelijk kunnen genezen omdat octrooihouders en big pharma vooral om hun profijt bezorgd zijn. Er moet in de mensenrechtengodsdienst zelfs niet gebiecht worden na de zonde, je doet gewoon voort. ${ }^{61}$

Maar hoe dan ook, moeizaam en gebrekkig, eerder dan vanzelfsprekend en effectief, ontwikkelt zich via het internationaal recht een nieuwe laag in het axiomatisch recht, in de constructie van de formele bronnen van het recht. In het referentie-apparaat van de juristen neemt een nieuwe zwaarwegende en hiërarchisch predominant genoemde laag van normen plaats die verdragsrechtelijk of via de 'rechtsbeginselen erkend door de beschaafde naties' (art. 38 Statuut Internationaal Gerechtshof, nog steeds met deze woorden geldig!) aangezet wordt. Dat wil zeggen dat van de Staten wordt verwacht dat ze via hun politieke systemen van rechten van de mens een harde rechtsbron gaan maken, hetzij door het aanspreken van het internationaal verdragsrecht of ius cogens, hetzij door eigen grondwettelijke formuleringen ervan. Dat zou het voor rechters dan mogelijk maken om ze juridisch af te dwingen.

\section{Mensenrechten als politieke koevoeten}

Het voorgaande leert dat op het verhaal over de mensenrechten veel kan worden afgedongen. Het gaat om een sterk Westers individualiserend verhaal dat de 'ecologische' interdependentie met de ander, zowel de menselijke als de niet-menselijke ander, geheel afhankelijk maakt van een denkbeeldige

61 Staten die het heel erg botvieren op mensenrechtenvlak (zoals China of Rusland bijvoorbeeld) blijven als puntje bij paaltje komt toch belangrijke handelspartners. 
individuele soevereiniteit als absoluut vertrekpunt. Het verhaal is bovendien historisch ingebed in een liberaal-kapitalistische stroming die zich graag als 'humanistisch' voordoet maar met brede bloedsporen en vernietigingen achter zich, het leven vrolijk cynisch de muur in stuurt. Markt, groei, productie en eigendom maken ons heersers en meesters van alles wat ons omringt. Pech voor degenen die gedepriveerd worden en voor alles wat vernietigd wordt, want we externaliseren toch alle schade en maken die lekker onzichtbaar via de truc van de economie en de geografische grenzen. ${ }^{62}$

Zijn we daarom tegen Amnesty International, Human Rights Watch of de Liga voor de mensenrechten? Neen, natuurlijk niet en wel integendeel. De wereld is wat ze is, en het is hier en nu dat er gehandeld moet worden. Grote abstracte bespiegelingen en religieuze ijkpunten uit een roemloos verleden kunnen ons daarbij niet helpen. Het handelen moet integendeel concreet zijn, ingebed in het nu, realistisch-speculatief en pragmatisch met de blik gericht op de consequenties, met zorg en voorzorg voor het leven in de toekomst. En uiteraard, met gebruik van de koevoeten en hefbomen die er zijn, als die een verschil, hoe klein ook, kunnen maken.

Organisaties zoals Amnesty en Human Rights Watch ontwikkelen zich als politieke actoren met topische slagkracht, dat wil zeggen dat ze specifieke situaties in een bepaalde en gewenste richting proberen te doen evolueren door mobilisatie van het mensenrechtendiscours. Samen met plaatselijke civil society organisaties die opkomen voor concrete strijdpunten leren ze ons de mensenrechten te bedienen als breekijzers om met betrekking tot bepaalde strijdpunten sterker te wegen. Of zij daarbij ook streven naar de realisatie van een abstract en theoretische mensenrechtelijk humanistisch

62 Europa het paradijs van de mensenrechten: de mensen die op bootjes creperen, dat is een probleem dat we wegkijken, of niet helemaal, we besteden het uit aan onze grote vrienden in Turkije en Libië. Over de onzichtbaarheid van economisch geweld en vragen over economische rechtvaardigheid in internationale mensenrechtenkwesties, en de band met de impliciete waarde in het dominant Westerse mensenrechtendiscours, Dustin Sharp, 'Addressing Economic Violence in Times of Transition; Toward a Positive-Peace Paradigm for Transitional Justice', Fordham Int'l L.J. 2012, vol. 35, (780-820), 796-801. Zie voor een alternatieve verklaring waarom bij transitional justice processen rectificatory justice kan domineren over legal en distributive justice, waarbij vooral deze laatste veronachtzaamd wordt, R. Mani, Beyond Retribution: Seeking Justice in the Shadow of War, Cambridge, UK: Polity Press, 2002, 256; P. Lundy \& M. McGovern, 'Whose Justice? Rethinking transitional justice from the bottom up', Journal of Law and Society, 2008, vol. 35(2), 274-275. Zie meer algemeen over het onvermogen van mensenrechten om sociale rechtvaardigheid te brengen, S. Moyn, Not Enough: Human Rights in an Unequal World, Cambridge: Harvard University Press, 2018, 220p.; P. Alston, 'The Populist Challenge to Human Rights', Journal of Human Rights Practice, 2017, vol. 9, 1-15. 
wereldbeeld, is daarbij wat ons betreft niet belangrijk. Koevoeten spelen in op zwakke plekken en het openbreken dat ze veroorzaken laat nieuw licht binnen (cf. motto Leonard Cohen) waardoor pragmatisch andere mogelijkheden kunnen worden geopend en te baat genomen, steeds lokaal en situatiegebonden. Zo worden de mensenrechten middelen om nieuwe en betere verhoudingen en situaties in het leven te roepen, die op hun beurt opnieuw enzovoort... en zodoende stapsgewijs kunnen bijdragen tot de constructie van een degelijker wereld. Er is echter niet veel dat ons vandaag toelaat te zeggen dat die betere toekomst vervat ligt in de wereldlijke verwerkelijking van de mensenrechtenreligie van vandaag: in het licht van de laatste 250 jaar wereldgeschiedenis, is dat eigenlijk vooral betwijfelbaar en allesbehalve hoopgevend.

Het lokaal en topisch actievoeren van organisaties als Amnesty situeert zich binnen, maar ook buiten het recht. Dat hoeft bij nader inzien niet te verbazen. Politieke en 'ethische' ('shaming') verantwoordingsmechanismen kunnen ertoe bijdragen dat onze verantwoordelijken aan het aarzelen slaan en zelfs responsief worden. Zij gaan dan mensenrechtelijke beleidsvoorstellen formuleren, autoriteiten systematisch onderwerpen aan een mensenrechtenmonitoring en actievoeren rond mensenrechtelijke pijnpunten. Daarbij kiezen ze soms voor juridische (bijvoorbeeld oproepen om mensenrechtenschenders te vervolgen) of voor niet juridische accountability (bijvoorbeeld druk uitoefenen op een mensenrechtenschender om terug te treden). De accountability beweging geleid door de genoemde mensenrechtenorganisaties is er precies gekomen om de strijd rond mensenrechten op een concreet, niet abstract idealistisch niveau te tillen, meer bepaald dat van de praktijk, dichtbij de mensen die geconfronteerd worden met conflicten ongeacht of die door de betrokkenen zelf in termen van mensenrechten of niet worden ervaren en beleefd. In deze benadering is verantwoording vragen en afdwingen een proces ${ }^{63}$ waarbij teruggevallen wordt op legale en niet-legale verantwoordingsmechanismen, die naast elkaar kunnen bestaan en elkaar aanvullen. Als mensenrechtelijke argumenten daarbij nuttig zijn en kracht toevoegen, is dat zeker meegenomen, mits ze maar bevrijd worden van universalistische noties en een klemtoon op de rol van de staat als behoeder ervan. ${ }^{64}$

63 T. Destrooper, 'Accountability for Human Rights Violations in Cambodia: Mapping the Indirect Effects of Transitional Justice Mechanisms', Asia-Pacific Journal on Human Rights \& the Law, 2018, vol. 19(2), (113-39), 116.

64 Vgl. met Amartya Sen, The Idea of Justice, London, Penguin Books, 2009, 467p. Sen zet Westerse en niet-westerse denkers in het licht die niet vertrekken vanuit een transcendentaal begrip over wat een juiste samenleving is maar vanuit de praktijk. Hoewel institutionele hervorming en sleutelen aan 'juiste instellingen' belangrijk zijn en blijven, komen we toch verder als we ons toespitsen op concrete sociale realisaties. Sen ziet daarbij de focus op staten als een tyrannie voor ons denken die ons doet 


\section{Mensenrechten als concrete rechtsmiddelen: juridische koevoeten in de rechtszaal}

Keren we terug naar de kern van de juridische activiteit, de beslechting van conflicten door de rechter en het juridische denken (of: het denken als rechters): de hermeneutische juridische praktijk die ervoor zorgt dat rechters en juristen zaken niet zomaar vrijelijk volgens hun goeddunken, maar strikt volgens de constraints van de juridische praktijk beslechten resp. anticiperen. Welke rol ligt daar weggelegd voor abstract en axiomatisch geformuleerde mensenrechten in grondwetten en internationale verdragen? Recht bedrijven en als jurist handelen is anders dan zwaaien met abstracte politieke idealen of economische dogma's. Niets is duidelijker dan de uitspraak 'roeien met de riemen die je hebt' als je als jurist handelt. Zo het axiomatisch recht - de normen die worden afgeleid uit de formele rechtsbronnen, en dus vooral de wetgeving - een enorme hoeveelheid aan algemene en minder algemene normen bevat, weet je tenslotte alleen met $100 \%$ zekerheid of je nu recht had of niet wanneer een rechter dat beslist (en nooit ervoor), en dat betekent dat een jurist zich, gegeven een bepaald probleem, moet vastbijten in de juridische interpretatieve stappen die een rechter binnen de constraints van de juridische praktijk mag, kán en zou kunnen zetten teneinde een beslissing te nemen. Daar de rechten van de mens deel uitmaken van de hiërarchisch hoogste formele rechtsbronnen, moeten ze ook aangewend worden in het kader van juridische creativiteit. Die creativiteit is een essentieel en

voorbijgaan aan ontelbaar verschillende lokale groepen, identiteiten en actoren. Utilitaristen, economische egalitairen, marxisten, libertariërs hebben allemaal hun kijk op perfecte instituties en op de ideale lijst van grondrechten en deze vallen nooit samen. Zonder in relativisme te vervallen, gaat Sen daarom een zoektocht naar rechtvaardige oplossingen voorstellen gebaseerd op empirie, bottom-up informatiegaring, evaluatie aan de hand van beoordelingscriteria (capabilities, mensenrechten gedacht als vrijheden, ...) en vergelijking van concrete alternatieven (die er altijd zijn). Universalisme of volledige consensus is daarbij niet nodig: 'For the emergence of a shared and useful understanding of many substantive issues of rights and duties (and also of rights and wrongs) there is no need to insist that we must have agreed complete orderings or universally accepted full partitions of the just, strictly separated from the unjust; for example, a common resolve to fight for the abolition of famines, or genocide, or terrorism, or slavery, or untouchability, or illiteracy, or epidemics, etc. does not require that there be a similarly extensive agreement on the appropriate formulae for inheritance rights, or income tax schedules, or levels of minimum wages, or copyright laws. The basic relevance of the distinct perspectives - some congruent, some divergent - of the people of the world (diversely diverse as we human beings are) is part of the understanding that open impartiality tends to generate. There is nothing defeatist in this recognition' (Amartya Sen, The Idea of Justice, London, Penguin Books, 2009, 139-140). 
broodnoodzakelijk kenmerk van de juridische praktijk: voor elk probleem moet de beste juridische oplossing gezocht worden. Dat men in de gevallen van juridische creativiteit al snel van 'juridisch activisme' spreekt zegt overigens iets over de staat van de rechtspraktijk ... Hoe dan ook: die creativiteit beantwoordt aan de rechterlijke plicht om in een bepaalde concrete situatie de best mogelijke juridisch verantwoorde definitieve beslissing te bewerkstelligen, in de hoop dat die misschien lokaal een situatie verbetert, en nog 'misschiener', later, als precedent of via de rechtsleer, een wat ruimer effect kunnen verkrijgen, zodat idealiter de wetgever erop zou inspelen etc. ${ }^{65}$

Het is niet voor niets dat Stanley Fish de rechtspraak de least dangerous branch noemde. Of zoals Rigaux het zei: rechters produceren trèves, 'wapenstilstanden' die altijd lokaal zijn, zelfs al moeten ze door eenieder erkend worden. De uitvoerende en de wetgevende macht kunnen er altijd voor zorgen dat er nooit meer een nieuwe rechter zoiets zal kunnen beslissen. Kortom, een realistische en pragmatische juridische creativiteit die zich inleeft in bestaande problemen en een zoektocht naar oplossingen zonder prekerige algemene/abstracte idealen belichaamt, kan zich zeker en vast bedienen van de mogelijkheden die de mensenrechten als hoge formele rechtsbron bieden. Er zijn wellicht scheurtjes en mogelijkheden in het normatieve axiomatische recht vervat: het is aan de juristen om er koevoeten in te wringen en te trekken en sleuren en hopen dat er wat licht doorkomt. Niets meer niets minder, maar elke gebeurtenis is een herschikking waarin mogelijkheden van verdere veranderingen vervat liggen. Het is het proberen zeker waard. ${ }^{66}$

65 Hierover: S. Gutwirth, 'Providing the missing link: law after Latour's passage', in K. McGee (ed.), Latour and the passage of law, Edinburgh U.P., 2015, 122-159; S. Gutwirth, 'Juridische correctheid' is nodig', Panopticon, 2015/5, Vol. 36, 425-432.

66 Of het inroepen van de rechten van de mens heilzaam zal zijn, is allesbehalve zeker. Het EVRM bevat inderdaad heel wat beperkingsmogelijkheden, die staten toelaten de betekenis van de fundamentele rechten ernstig te beknotten. We spraken al van de 'subsidiariteit' van het verdrag en de 'margin of appreciation', maar het gaat nog een stuk verder. Krachtens art. 15 kunnen zowat alle rechten op een laag pitje gezet worden als er een toestand heerst die 'het voortbestaan van het land' bedreigt (terrorisme of de coronacrisis), terwijl voor andere rechten (uitingsvrijheid, privéleven, vrijheid van vergadering en gewetensvrijheid) de beperkingsvoorwaarden expliciet worden ingecalculeerd. Waar we ons in de jaren '90 nog druk maakten omwille van de plaatsing van caméra's of het afluisteren van telefoongesprekken, is het vandaag de dag zo dat zulke vormen van surveillance, dankzij de beperkingsmogelijkheden, geheel gebanaliseerd zijn geraakt, en dat big data en het gebruik dat ervan gemaakt wordt eigenlijk ontsnappen aan elke controle, al was het maar omdat die voorbij de controlemacht van de staat worden verwerkt en verhandeld. Het gaat zelfs zover dat respectabele instellingen zich gegevensverwerkinssystemen aanschaffen waarvan iedereen weet dat ze niet conform zijn noch met de mensenrechten, noch met data protection. Overigens blijven maatregelen die genomen worden tijdens een 'crisis' oneindig veel 


\section{Uitleiding: een veel te machtig en toxisch seculier geloof}

We weten dat Sonja Snacken door onze geschriften over de polyfonische rechtsstaat en, net als wij, het relationeel rechtsbegrip van Foqué en 't Hart is beïnvloed geweest. ${ }^{67}$ Het is natuurlijk een verhaal waarmee je in de huidige politieke constellatie iets kunt, omdat het, met zijn nadruk op grondrechten en checks and balances, teruggrijpt naar de grondslagen van het Westerse politieke denken 250 jaar heeft getekend, en eigenlijk min of meer als politiek filosofische constitutie kan gelden. Het geeft binnen het systeem aanvaardbare en sterke argumenten, die schenders van zijn basisbeginselen kunnen doen wankelen en aarzelen. Wij zelf zullen niet nalaten het te gebruiken en te mobiliseren, als het van pas komt in het topische recht, in de rechtspraktijk. We zullen het blijven vertellen aan onze studenten, omdat het een sterk gedragen verhaal is met stringente gevolgen voor de structurering en organisatie niet alleen van onze samenleving maar ook die van de anderen, zelfs al hebben die erom niet gevraagd. De rechten van de mens zijn als formele rechtsbron een reëel en zelfs onomzeilbaar middel zowel voor rechtzoekenden, als voor juristen en rechters. Als je een verbod tot betogen kan aanvechten met art. 10 EVRM, dan moet je dat zeker doen; als je geen zin hebt dat de GAFAMs je doen en laten minutieus volgen en in kaart brengen, moet je het

langer in stand gehouden dan ter oplossing van de crisis nodig is. Over de rol van de rechter was Rigaux overigens al allesbehalve optimistisch: « (C)ertains instruments normatifs qui expriment les aspirations fondamentales des hommes et des femmes de leur temps et proclament un message clair et même exaltant se révèlent dans la pratique d'un maniement beaucoup plus complexe. Tel est notamment le cas de la Déclaration des droits de l'homme et du citoyen du 26 août 1789, dont les principes ont été réitérés dans le préambule de la Constitution de la Ve République et dont le langage a aussi inspiré la Convention de sauvegarde des droits de l'homme et des libertés fondamentales du 4 novembre 1950. Ces instruments paraissent découper des plages aérées, ils promettent en des termes accessibles à tous, la liberté d'expression, la liberté d'association, l'égalité devant la loi, la protection contre l'arbitraire. Toutefois, dès que les juges s'emparent de la violation alléguée d'une liberté fondamentale, ils développent un discours qui laisse voir combien sont incertaines les frontières des espaces protégés : la religion des droits de l'homme se transforme en culte savant " (F. Rigaux, La loi des juges, Odile Jacob, Paris, 1997, 8). En het is zeker juist dat rechters, en in het bijzonder die uit het Straatsburgse Hof, hoe integer ze ook zijn, zeer dikwijls komen te staan voor proportionaliteitsoverwegingen en belangenafwegingen, waarbij zij, zelfs binnen hun verplichtingen als juristen, zelf en eigenmachtig beslissen over de toegemeten gewichten, de ijking en het doorslaan van de balans.

67 S. Gutwirth, 'De polyfonie van de democratische rechtsstaat' in Wantrouwen en onbehagen, M. Elchardus, (red.), Balans 14, Brussels, VUBPress, 1998; R. Foqué \& A.C. 't Hart, Instrumentaliteit en rechtsbescherming. Grondslagen van een strafrechtelijke waardendiscussie, Arnhem/Antwerpen, Gouda Quint/Kluwer, 1990, 501p. 
zeker niet nalaten om dat aan te vechten via juridische procedures rond de bescherming van je vrijheid, je privéleven en je persoonsgegevens.

Noem het vooruitschrijdend of resurgent inzicht, maar na de Westerse euforie van de Golden sixties en de successen van de West-Europese welvaartstaat (als we Foucault pour le besoin de l'argument even vergeten), is het verhaal van de polyfonische democratische rechtsstaat en de universele rechten van mens, in het aanschijn van het neoliberale kapitalisme met zijn steeds ondraaglijker wordende uitwassen (zelfs tegen de zó hoog geprezen 'individuele vrijheid') en de bewustwording van de gemene brutaliteit waarmee het Westen de rest van de wereld, het leven en de atmosfeer, heeft onderworpen aan zijn vernietigende hebzucht, de rol gaan spelen van een veel te machtig en toxisch geworden seculier geloof. Met zijn 'einde van de geschiedenis' heeft Fukuyama dat mooi verwoord: alleen een allesomvattend zelfgenoegzaam en een blind monotheïsme kan zo'n irrealistische en dogmatische stelling onderbouwen. Gebruik de fundamentele rechten als politieke en juridische middelen als het helpen kan, maar geloof vooral niet dat ze een panacée, een opperste arbiter of een finaal ijkpunt zijn. Mensenrechten zijn deel van een verhaal dat morgen, in het aanschijn van wat het verdoezelt, zijn overtuigingskracht kan verliezen. Het is een foute strategie om de geschiedenis van dat individualistische en op de markt geënte verhaal op te blazen en te koppelen aan noties zoals universalistische geldigheid. Het is eveneens een foute strategie om dit verhaal het enige legitieme verhaal te noemen. Het is allesbehalve 'evidence based', laat staan realistisch te blijven geloven dat we allemaal gelijke, vrije en soevereine individuen zijn.

Op de klassieke dooddoeners, met name de verongelijkte vragen 'wat ons alternatief dan is?' en 'wat we dan in de plaats gaan zetten?' hebben we een eenvoudig antwoord. Geef ons ook 250 jaar tijd, en we maken er, bottom up, niet als individuele calculerende en ontwortelde egoïsten maar als ecologische en verbonden wezens, zonder gewapende staten als machtige gendarmen, in onderlinge samenwerking, zonder meerderheid-minderheid regel maar met consensueel-speculatieve palavers, en zonder externalisatie van schade, risico en miserie, zeer zeker iets beters van. 